\title{
Brugada Syndrome Diagnosed with COVID-19 Infection
}

\author{
Berat Uğuz, (1) Selma Kenar Tiryakioğlu, (1) Mustafa Yılmaztepe, (1) Selvi Öztaş, \\ İsmet Zengin \\ Department of Cardiology, Bursa City Hospital, Bursa, Turkey
}

\section{ABSTRACT}

The COVID-19 outbreak is a global public health problem, the disease has spread exponentially since the late December 2019, when the first cases of SARS-CoV-2 infection were detected in Wuhan, China. Fever is the most common symptom in about $88 \%$ of cases, cough (68\%), vomiting (5\%), and diarrhea (3.8\%) are the other common symptoms. In this case report, a 34-year-old male patient admitted to the emergency department with fever lasting for 3 days. The first diagnostic study, including documented computed tomography scan, was consistent with viral pneumonia and the 12 lead electrocardiogram (ECG) showed a Brugada-type I pattern, ST segment elevation in the right precordial leads with no reciprocal changes. The patient had no chest pain, or syncope or a family history of sudden cardiac death. Cardiac enzymes were normal and echocardiographic examination showed normal wall motions and there was no pericardial effusion. The patient was hospitalized with a diagnosis of COVID-19 pneumonia confirmed by a positive nasopharyngeal swab test for COVID-19. Brugada syndrome is a rare disease manifested by ST-segment elevation in the right precordial leads. Fever may cause Brugada-like changes in the ECG. With the reduction of fever, the Brugada-like ECG changes also disappeared.

Keywords: Arrhythmia, brugada syndrome, COVID-19

Please cite this article as: Uğuz B, Kenar Tiryakioğlu S, Yılmaztepe $M$, Öztaş S, Zengin I. Brugada Syndrome Diagnosed with COVID-19 Infection. Anatol J Family Med 2021;4(1):95-97.

Address for correspondence: Dr. Berat Uğuz. Department of Cardiology, Bursa City Hospital, Bursa, Turkey

Phone: +90 5424902422

E-mail:

beratuguz33@hotmail.com

Received Date: 04.08.2020

Accepted Date: 04.09.2020

Published online: 10.03.2021

(C) Copyright 2021 by Anatolian Journal of Family Medicine -

Available online at Www.anatoljfm.org

OPEN ACCESS

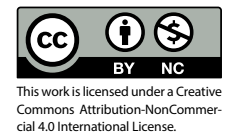

\section{INTRODUCTION}

Brugada syndrome (BS) is an autosomal dominantly inherited genetic disease. The characteristic finding of BS is ST-segment elevation in V1-3 derivations and right bundle branch block pattern in patients without structural heart disease. ${ }^{[1]}$ Mutations in the SCN5A gene, which is responsible for the regulation of sodium channels, held responsible for the pathophysiology. ${ }^{[2]}$ BS is usually seen in men and is thought to be responsible for about $4 \%$ of all sudden deaths. ${ }^{[3]}$ Syncope or sudden cardiac death may be the first sign of BS. ${ }^{[4]}$

Electrocardiogram (ECG) findings of BS are dynamic, in some cases, ECG findings may appear normal. Fever, alcohol, $\alpha$-adrenergic agonists, $\beta$-adrenergic blockers, tricyclic antidepressants, hyperkalemia, hypokalemia, hypercalcemia, sodium channel blockers (ajmaline, flecainide, propafenone, etc.) can cause typical ECG findings in these patients. ${ }^{[5]}$ In this case report, we present a case of BS in which ECG findings become apparent as a result of high fever due to Coronavirus infection.

\section{CASE REPORT}

A 34-year-old male patient presented the emergency department with high fever ongoing for 3 days. Physical examination was unremarkable except high fever $\left(39^{\circ} \mathrm{C}\right)$, blood pressure was $120 / 75 \mathrm{mmHg}$ and pulse rate was 116 beats $/ \mathrm{min}$. The initial diagnostic workup involving chest computed tomography (Fig.1) was consistent with viral pneumonia and a nasopharyngeal swab test was performed for Covid-19, which later confirmed the diagnosis. Laboratory 


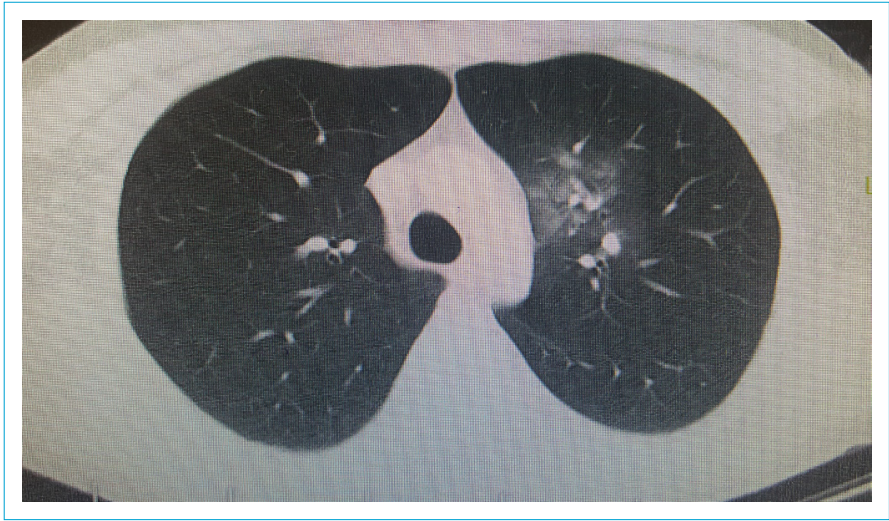

Figure 1. Chest computed tomography image of the patient.

tests revealed high C-reactive protein (CRP) $(78.6 \mathrm{mg} / \mathrm{L})$ and sedimentation rate $(27 \mathrm{~mm} / \mathrm{hr})$. The patient was hospitalized and hydroxychloroquine treatment was planned. The pre-treatment ECG displayed a right ventricular conduction delay and a more than $2 \mathrm{~mm}$ ST elevation in leads V1-V2-V3 (Fig. 2). The ECG was thought to have a Type 1 pattern in Brugada. Troponin ( $3 \mathrm{mg} / \mathrm{L}$ ) and $\mathrm{N}$-terminal brain natriuretic peptide ( $28 \mathrm{ng} / \mathrm{L}$ ) were found within normal limits. Transthoracic echocardiographic examination normal left and right ventricular functions were detected without any wall motion abnormalities, chamber dilatation or pericardial effusion. The patient's medical and family history was also unremarkable without any syncope or sudden cardiac death.

The patient was given hydroxychloroquine $(2 \times 200 \mathrm{mg}$ maintenance dose followed by $2 \times 400 \mathrm{mg}$ ), ceftriaxone (3x1 gr, IV) and paracetamol treatment. On the second day, his temperature was measured as $38.3^{\circ} \mathrm{C}$ and the ECG was taken again (Fig. 3). With the regression of the patient's fe$\operatorname{ver}\left(36.7^{\circ} \mathrm{C}\right.$ on day 4$)$, the Brugada type pattern on the ECG disappeared (Fig. 4). Infection parameters also decreased (CRP $8.3 \mathrm{mg} / \mathrm{dL}$ and sedimentation rate $11 \mathrm{~mm} / \mathrm{hr}$ ).

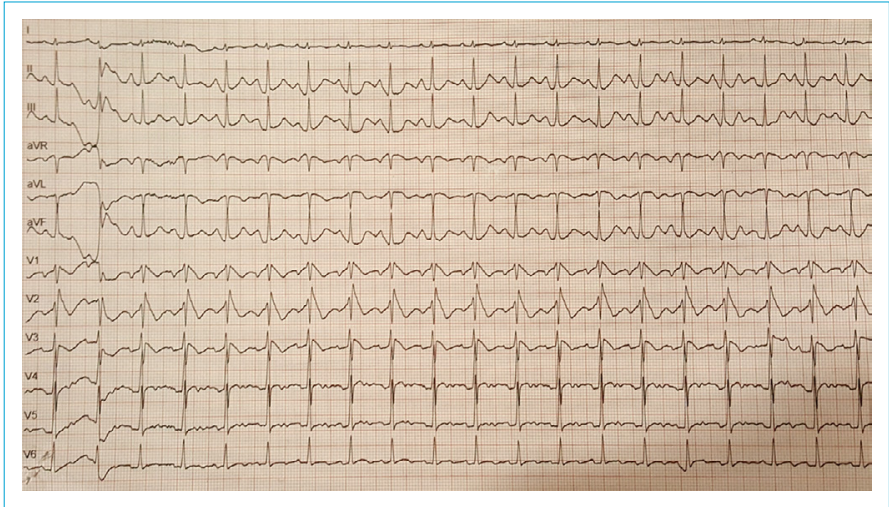

Figure 2. The patient's initial 12-lead electrocardiogram in the emergency department.

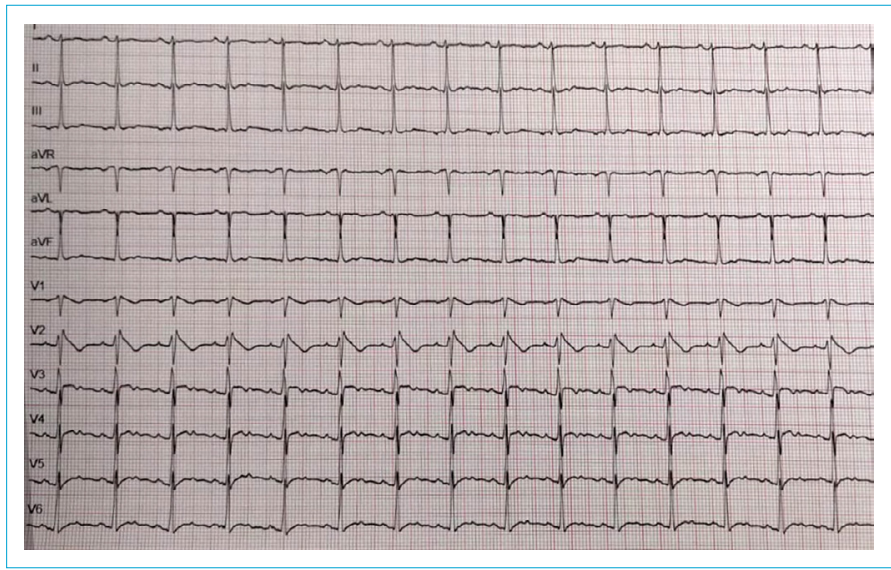

Figure 3. The patient's initial 12-lead electrocardiogram on the second day.

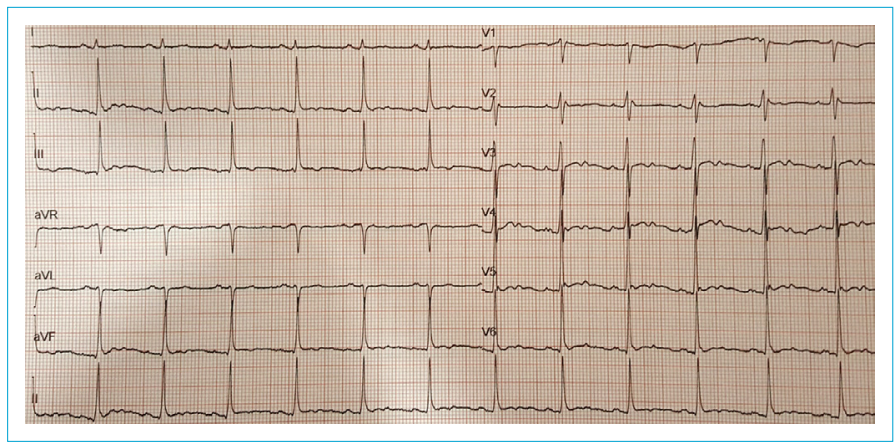

Figure 4. The patient's repeat 12-lead electrocardiogram with resolution of fever.

There was no arrhythmia during his hospitalization. Since there was no arrhythmic event or a history of syncope and no family history of sudden cardiac death, there was no need to place a defibrillator. The patient was discharged uneventfully with the recommendations to avoid medications that may cause Brugada-like ECG changes and to reduce the fever immediately when he has a fever.

\section{DISCUSSION}

BS is an autosomal dominantly inherited channelopathy characterized by ST-segment elevation in right precordial leads and right bundle branch block. ${ }^{[1]}$ Three types of ECG repolarization patterns have been described in the right precordial leads. Type 1 is the diagnosis of BS and is characterized by a coved ST-segment elevation above $2 \mathrm{~mm}(0.2 \mathrm{mV})$ followed by a negative T wave. Type 2 ST-segment elevation has a saddleback appearance with a high takeoff ST-segment elevation of $\geq 2 \mathrm{~mm}$, atrough displaying $\geq 1 \mathrm{~mm} \mathrm{ST}$ elevation, and then either a positive or biphasic T wave. Type 3 has either a saddleback or coved appearance with an ST-segment elevation of $<1 \mathrm{~mm} \cdot{ }^{[3]}$ Type 2 and 3 ECG findings are not diagnostic for BS, therefore patients with these type of ECG abnormalities and symptoms such as syncope or family history 
of sudden cardiac death should be suspected and investigated further for BS. The administration of a sodium channel blocker (flecainide, ajmaline, procainamide, or propafenone etc.) would unmask Type 1 ECG and confirm the diagnosis of BS. During this test, patients should have a good rhythm control due to the risk of severe arrhythmia. Some clinical conditions (drug use, hyperthyroidism, electrolyte disorder, fever) should be treated as they may increase the frequency of arrhythmia in $\mathrm{BS} .^{[3]}$

Fever has been shown to accelerate arrhythmia in patients with BS, and a study showed that more than half of the study group had syncope or cardiac arrest in case of high fever. ${ }^{[4]}$ Mizusawa et al. found that patients with fever-induced Type 1 ECG of BS increased the risk of syncope and ventricular fibrillation. ${ }^{[6]}$ Michowitz et al. reported that premature inactivation of the sodium channel is accentuated at higher temperatures. According to them, febrile conditions can unmask patients with BS and can temporarily increase the risk of arrhythmia, especially in male Caucasian patients. ${ }^{[7]}$

The new Corona virus (COVID-19) outbreak is a global problem responsible for acute pneumonia cases. The virus is transmitted between humans and the outbreak was declared a pandemic by the World Health Organization on 11 March 2020. ${ }^{[8]}$ The most common clinical symptom is fever (88.7\%). Other symptoms include cough (67.8\%), shortness of breath (18.7\%), myalgia or arthralgia (14.9\%), sore throat $(13.9 \%)$ headache $(13.6 \%)$, diarrhea $(3.8 \%)$, sputum (33.7\%) and fatigue. (38.1\%). ${ }^{[9]}$ In this article, we presented a case of BS with Type 1 ECG characteristics caused by fever due to COVID-19 infection. Although there is no specific treatment recommendation for patients with $\mathrm{BS}$, we have started hydroxychloroquine, ceftriaxone and paracetamol treatment. ${ }^{[10]}$ No arrhythmia was observed in the patient, and the patient was discharged as a result of regression of infection parameters and fever.

\section{Disclosures}

Conflict of Interest: Written informed consent was obtained from the patient for the publication of the case report and the accompanying images.

Conflict of Interest: The authors have no relevant conflicts of interest to disclose.
Peer-review: Externally peer-reviewed.

Authorship contributions: Concept - B.U., S.K.T. ; Design - B.U., S.K.T., S.Ö.; Supervision - M.Y., I.Z. ; Materials - M.Y., İ.Z.; Data collection \&/or processing -B.U., S.Ö.; Analysis and/or interpretation - S.K.T.; S.Ö.; Literature search - B.U., İ.Z.; Writing -B.U. ; Critical Review -B.U.

\section{REFERENCES}

1. Miyazaki T, Mitamura H, Miyoshi S, Soejima K, Aizawa Y, Ogawa S. Autonomic and antiarrhythmic drug modulation of ST segment elevation in patients with Brugada syndrome. J Am Coll Cardiol 1996;27(5):1061-70. [CrossRef]

2. Satish OS, Yeh KH, Wen MS. Brugada syndrome--an update. Chang Gung Med J 2005;28(2):69-76.

3. Antzelevitch C, Brugada P, Borggrefe M, Brugada J, Brugada $\mathrm{R}$, Corrado $\mathrm{D}$, et al. Brugada syndrome: report of the second consensus conference: endorsed by the Heart Rhythm Society and the European Heart Rhythm Association. Circulation 2005;111(5):659-70. [CrossRef

4. Chang D, Saleh M, Garcia-Bengo Y, Choi E, Epstein L, Willner J. COVID-19 infection unmasking Brugada syndrome. HeartRhythm Case Rep 2020;6(5):237-40. [CrossRef]

5. Sarquella-Brugada G, Campuzano O, Arbelo E, Brugada J, Brugada R. Brugada syndrome: clinical and genetic findings. Genet Med 2016;18(1):3-12. [CrossRef]

6. Mizusawa $Y$, Morita $H$, Adler A, Havakuk O, Thollet A, Maury $P$, et al. Prognostic significance of fever-induced Brugada syndrome. Heart Rhythm 2016;13(7):1515-20. [CrossRef]

7. Michowitz Y, Milman A, Sarquella-Brugada G, Andorin A, Champagne J, Postema PG, et al. Fever-related arrhythmic events in the multicenter survey on arrhythmic events in Brugada syndrome. Heart Rhythm 2018;15(9):1394-401. [CrossRef]

8. Zhu N, Zhang D, Wang W, Li X, Yang B, Song J, et al; China Novel Coronavirus Investigating and Research Team. A novel coronavirus from patients with pneumonia in China, 2019. N Engl J Med 2020;382(8):727-33. [CrossRef]

9. Guan WJ, Ni ZY, Hu Y, Liang WH, Ou CQ, He JX, et al; China Medical Treatment Expert Group for Covid-19. Clinical characteristics of coronavirus disease 2019 in China. N Engl J Med 2020;382(18):1708-20. [CrossRef]

10. Wu Cl, Postema PG, Arbelo E, Behr ER, Bezzina CR, Napolitano C, et al. SARS-CoV-2, COVID-19, and inherited arrhythmia syndromes. Heart Rhythm 2020;17(9):1456-62. [CrossRef] 